\title{
Behavior of Surface Sediment from the José Antonio Alzate Dam in Mexico as a Deposit of Heavy Metals
}

\author{
Icela Dagmar Barceló-Quintal*, Hugo Eduardo Solís-Correa, Julisa García-Albortante, \\ Magdalena García-Martínez, Luis Jesús Osornio-Berthet
}

Area of Chemistry and Physical Chemistry Environmental, Division of Basic Sciences and Engineering, University

Autonomous Metropolitan-Azcapotzalco, Mexico City, Mexico

Email: ^ibarceloq@gmail.com

How to cite this paper: Barceló-Quintal, I.D., Solís-Correa, H.E., García-Albortante, J., García-Martínez, M. and Osornio-Berthet, L.J. (2018) Behavior of Surface Sediment from the José Antonio Alzate Dam in Mexico as a Deposit of Heavy Metals. Journal of Environmental Protection, 9, 1049-1065. https://doi.org/10.4236/jep.2018.910065

Received: March 11, 2018

Accepted: September 4, 2018

Published: September 7, 2018

Copyright $\odot 2018$ by authors and Scientific Research Publishing Inc. This work is licensed under the Creative Commons Attribution International License (CC BY 4.0).

http://creativecommons.org/licenses/by/4.0/

\begin{abstract}
The problem of contamination of Lerma River in the State of Mexico, México, has been studied in an integral way, since it is one of the rivers of importance due to its geographical situation in the country. José Antonio Dam is the main receiving body of this river that is being contaminated by, industrial wastewater, of which about $70 \%$ is inorganic, as well as discharges municipal and agricultural, driving a lot of material in suspension. This dam acts as a regulator of avenues and its water is used for agricultural irrigation and its sediments are used as sludge to improve agricultural soil in the surroundings. One of the studies that have been carried out is to determine the geochemical distribution of heavy metals in the sediments of this dam, as well as its adsorptive capacity towards different metals. It has been observed that these sediments acts as metal contaminants sequester. Knowing the composition and morphology of these sediments can provide information to understand the mobility of different heavy metals it contains, and potential health risk, which can finally lead to the establishment of purification capacity of this sludge.
\end{abstract}

\section{Keywords}

Lerma River, José Antonio Alzate Dam, Sediment, Heavy Metal

\section{Introduction}

It has been observed that natural processes for the formation of aquatic sediments are altered by human activities and are recognized as a reservoir for different chemical species, including metals [1] [2] [3]. The sediment has a great diversity of components, such as, clays, inorganic colloids as $\mathrm{Fe}$ and $\mathrm{Al}$ oxyhydroxides and soil organic matter which consists of humic substances and par- 
tially decomposed biomass. All of these components present large areas of interaction that allows a wide variety of metals to be incorporated by different processes. According to [4], the sediments are formed by sand and gravel (2.00 $0.20 \mathrm{~mm})$, fine sand $(0.20-0.02 \mathrm{~mm})$, silt $(0.02-0.002 \mathrm{~mm})$ and clay with smaller grain sizes of $0.002 \mathrm{~mm}$. The finer sediments, which generally contain higher concentrations of metals, accumulate in calm waters such as lakes, dams, etc. [5]. The oxyhydroxides of $\mathrm{Al}, \mathrm{Fe}$ and $\mathrm{Mn}$ present in the sediments adsorb trace metals where the clays function as a support for organic matter and these oxyhydroxides. Metals are joined to sediments by different physicochemical phenomena, but even so the metals do not remain fixed in sediment [1] [6], since they can present chemical changes due to the physicochemical changes of environment that surrounds them. Physicochemical phenomena controlling the sedimentation processes and association mechanisms of the different pollutants and nutrients depends variables like $\mathrm{pH}$, temperature and dissolved oxygen (OD). Metals interaction processes with sediments are very complex, and the sediment-water system has relevance in different chemical reactions of metals such as adsorption and desorption equilibria.

Considering that sediments are complex systems where each metal has affinity to one or more of its components. The procedure of sequential extractions (chemical speciation) using chemical extractors to separate part of a metal associated with a component of the sediment, this technique has been successfully used for sediment characterization; the method most used to estimate the metallic reactivity in several types of particles enriched with adsorbed metals, has been developed since its inception by Tessier et al. in Canada [7], in Germany, Calmano and Förstner [4] [8], in Mexico, Barceló [9], Barceló et al. [1], Quecholac, [10], Badillo-Camacho et al. [11], among others in different countries, to develop the techniques, to optimize and to modify others, including Benson et al. who published a review of the different analytical methods that have been used by researchers regarding sequential extractions [12]. The most common fractions have been established in a methodological scheme that consists of:

* (F1), first extracted fraction called "Interchangeable" [7], comprises weakly adsorbed metal ions that can be released from sediment surface with changes in the ionic composition of water.

* (F2), fraction called "Acid-Soluble" [5], relates to metals present in the sediment mainly as carbonates and can be re-dissolved if there is a decrease in $\mathrm{pH}$ in the aqueous medium.

* (F3) and (F4), fractions called "Easily Reducible" and "Hardly Reducible" respectively, contains the highest percentage of metals sequestered between nodules or cemented particles, in the first case, related to oxyhydroxides of $\mathrm{Mn}$ and in the second case related to oxyhydroxides of Fe; they are thermodynamically unstable under anoxic conditions and low reduction potentials [5] [7] [8].

* (F5), fraction denominated "Oxidable" in which metals are linked to different forms of organic matter; under oxidizing conditions organic matter is trans- 
formed and released metals which are forming soluble salts.

* (F6), fraction "Residual" or fixed is the one that can to hold back metals in its crystalline network.

On the other hand, considering the location area where this study was developed, it is necessary to indicate that, The Toluca Valley is located in Mexico State, México, has an important agricultural production and an accelerated urban-industrial growth, presents the problem that its aquifers are being overexploited and at the same time contaminating to Lerma River, main river of the zone, by to discharge of urban wastewater and of industrial discharges located in the industrial zone "Toluca-Lerma", since it is one of the rivers of importance due to its geographical situation in the country. This river belongs to the Upper Basin of the Lerma River that starts in lagoons of Almoloya del Río with the concurrence of different tributaries, receiving the first discharges of wastewater between three and five kilometers, from its birth; continuing its trajectory and between ten and twelve kilometers it receives important discharges of wastewater, since in this section waters converge and coming from urban-industrial zone of Santiago Tianguistenco and its industrial parks I and II, Santa Cruz Atizapán and Ocoyoacac, which is the urban-industrial zone Toluca-Lerma, the municipal wastewater contributions of San Mateo Atenco, Metepec and the town of Lerma itself. The Lerma River crosses five states and finally discharges into Lake Chapala. Both the anthropogenic turns and the climate change have altered the sanitary conditions of the river throughout its journey, seriously affecting the biota that has already been extinct and especially the Lake Chapala. José Antonio Alzate Dam is the main receiving body of this river, was built in 1965 for flood control and agricultural irrigation, currently is being contaminated by, industrial wastewater, of which about $70 \%$ is inorganic, as well as discharges municipal and agricultural, driving a lot of material in suspension [13] [14]. This problem occurs along the course of the river until Lake Chapala where it ends and introduces more pollutants such as metals, strongly affecting this important lake in the country [11]. This river is in bad conditions all time because is used as a public wastewater collector, losing the signs of aquatic life. It is important to point out the competition that is established for the use of water, both by the city, as by industry and agriculture, since all three need large quantities [1] [8]. Uncontrolled discharges of wastewater, municipal and industrial, untreated or partially treated, and runoff of waters used in agricultural irrigation, involve continuous pollution of Lerma River affecting its utility for multiple uses. Heavy metal contamination is usually associated with municipal discharges and industrial processes that go directly to aquifers, but is also related to the leaching of wastes, solid discharges and weathering of rocks which provide contaminants to a fluvial system.

Among the anthropogenic waste discharged into the river, are the heavy metals that affect the José Antonio Alzate dam, this reservoir allows a work to purify the waters of the Lerma River and tributaries, although it has not been designed to it [15]. For years a large amount of industrial and urban waste has been dis- 
charged into the Lerma River from its source to the Alzate dam, causing a serious impact on the quality of its water for the subsistence of the biota and in part to the irrigation of the area adjacent to the dam. The river runs through North of State and when it discharges to reservoir it arrives loaded with the drains of the Toluca City, surrounding villages and industrial zone, which determines that dam presents the worst conditions in its quality. Metals are used in industrial processes and are emitted to environment altering the aquatic system of dam, where they are trapped and accumulate due to the sedimentation dynamics. In addition, the presence of different chemical species that can form cations and anions will enter through the different operations of coagulation, flocculation and decantation, to be part of the sediments themselves [9]. Contamination level of Alzate Dam varies according to season of year, as well as water levels. However, in all seasons of the year, the sediments function as a good metal entrapment system [2]. What implies a contamination of these sediments, which has been evaluated according to some standards and recommendations, since no Mexican standardization was found, the use of criteria from government agencies of Canada and the United States for disposal of sludge from bodies of water has been suggested, such as The Ontario Ministry of the Environment (MOE) [16], The Thomas-Mudroch Agency [17] and The United Environmental Protection Agency (EPA) [18]. Table 1 shows these criteria for several metals.

Table 1. Recommended criteria for sediments (mg/kg).

\begin{tabular}{cccc}
\hline Metal & MOE criterion & Thomas-Mudroch criterion & $\begin{array}{c}\text { EPA criterion for } \\
\text { severe contamination }\end{array}$ \\
\hline Cadmium & 1 & 1.5 & 6 \\
Copper & 25 & 45 & 50 \\
Iron & 10,000 & 45,500 & 25,000 \\
Manganese & - & 1625 & 500 \\
Lead & 50 & 50 & 60 \\
Zinc & 100 & 105 & 200 \\
\hline
\end{tabular}

\section{Materials and Methods}

Three important areas of the Alzate dam were studied, which were called A, B, and $\mathrm{F}$; where $\mathrm{A}$ is the entrance of Lerma river to the dam, therefore of alluvial carries and of agro-industry material; B zone is of greater sedimentation, according to Barceló, 2000; [9] and F zone where the dam's curtain is located and the river outflow. COD in spring, sediment composite samples were collected from three sites in each zone at a circular distance of three meters each. Each sediment core obtained was of $20 \mathrm{~cm}$ thick, using a gravity type nucleator and placed in polyethylene bags. Sediments were collected during dry season on 2012-2014 years; season where metals are concentrated in sediments; in each sampling sediment had excess water, it was necessary to eliminate this by solar drying, where sediment was placed in plexiglass trays during 10 days; with each sediment sampled in the indicated years, composite samples prepared one more time. 


\subsection{Sediments Composition}

The drying of a part of the each sediment was completed by lyophilization, ground and sieved using US sieves. Tyler 60, 100, 250, 325 and 400 mesh, for the analysis of X-Ray Fluorescence (FRX), X-Ray Diffraction (XRD), Scanning Electron Microscopy (SEM), granulometry and determination of organic matter, the sediment retained in 100 mesh was used. Sediment retained to 400 meshes was used for chemical speciation studies. For total metals the weighted sum of each fraction of chemical speciation was used. For Textural and Granulometric classification of sediment, Bouyoucos hydrometric method and texture triangle were used. The volatile material determination was through weight loss, $1 \mathrm{~g}$ of sediment was heated in a Thermolyne 53,600 muffle for 3 hours at $150^{\circ} \mathrm{C}, 300^{\circ} \mathrm{C}$ and $500^{\circ} \mathrm{C}$, residual material was weighed after each stage. The weight of material removed in each sample for different temperatures was calculated by difference, all operations were carried out in triplicate.

\subsection{Metallic Concentrations Determination from Each Sequential Extraction}

Each concentration was determined using technique of sequential extractions for obtain the geochemical distribution of each metal (speciation) in sediment of three zones of the dam. Six fractions were obtained using chemical extractors in each case [7] [9] [19]. The fractions were named F1 (exchangeable), F2 (acid-soluble), F3 (easily reducible), F4 (hardly reducible), F5 (oxidizable) and F6 (residual). Fractions F1, F2 and F3 are the most mobile fractions. A change in ionicity of the medium, such as for example, those due to industrial discharges of soluble inorganic compounds or a $\mathrm{pH}$ change caused by rains or discharges can extract and redissolve the associated metals. The fractions F4 and F5 can be considered almost fixed, and F6 fraction totally fixed and of little risk. It is important to mention that after each extraction treatment the material was lyophilized for the next extraction successively. Each extract were treated by acid digestion using $\mathrm{HNO}_{3} / \mathrm{HF}$ (1:2) Suprapur Merck in a microwave oven (CEM model 5 MARS, USA) for further analysis by Atomic Absorption spectrophotometry by graphite furnace (the first five fractions for $\mathrm{Cd}, \mathrm{Cu}$ and $\mathrm{Pb}$ ) and flame (for residual fractions of all metals) in a SOLAAR M6 (Thermo Elemental, England) equipment, each operation was performed in three times.

Sequential extractions technique by lyophilization was selected following the Quecholac methodology, where metals such as $\mathrm{Cu}, \mathrm{Fe}, \mathrm{Mn}$ among others were evaluated in their thesis work [10], optimizing both, continuous (traditional) method and lyophilized method. In Table 2 the results for $\mathrm{Cu}, \mathrm{Fe}$ and $\mathrm{Mn}$, are presented, although lyophilization method it is a little longer, when to add all fractions of metal speciation, the value obtained by lyophilization, is closer to the value measurement to the total metal concentration than the value obtained by the continuous method. It is also important to mention that each analysis was 
done in this with sediment from zone B of J. A. Alzate dam.

Table 2. Comparison of sequential extractions techniques with respect to measurements of total metals.

\begin{tabular}{cccccc}
\hline Metal & $\begin{array}{c}\text { Total } \\
\mathbf{m g} / \mathbf{k g}\end{array}$ & $\begin{array}{c}\text { Total fractions } \\
\text { continuous } \\
\text { method } \mathbf{m g} / \mathbf{k g}\end{array}$ & $\begin{array}{c}\text { Total fractions } \\
\text { lyophilization } \\
\text { method mg/kg }\end{array}$ & $\begin{array}{c}\text { \% mistake } \\
\text { continuous } \\
\text { method }\end{array}$ & $\begin{array}{c}\text { \% mistake } \\
\text { lyophilization } \\
\text { method }\end{array}$ \\
\hline $\mathbf{C u}$ & 50.04 & 54.142 & 48.875 & 8.19 & 2.32 \\
$\mathbf{F e}$ & 35547.70 & 46825.64 & 37516.73 & 31.72 & 5.54 \\
$\mathrm{Mn}$ & 208.71 & 220.64 & 205.86 & 5.72 & 1.37 \\
\hline
\end{tabular}

\subsection{Sediment Quality Evaluation from A, B and F Zones}

Based on the criteria indicated in Table 1, was evaluated the sediment of zones $\mathrm{A}, \mathrm{B}$ and $\mathrm{F}$ from Alzate dam, considering in each case six fractions, obtained from the sequential extractions, and the first five removing the residual fraction F6, where practically the $\mathrm{Pb}$ is trapped in the crystalline lattices and it is difficult for it to pass into aqueous phase.

\section{Results and Discussion}

\subsection{Texture and Granulometry Classification of the Sediment}

To classify the granulometry and texture of sediments, triangle of textures and the Bouyoucos technique were used respectively; the sediment composition of each area from Alzate dam is presented in \% of distribution. Zone A presented the highest \% of silt, classified as sandy-loamy $(\mathrm{Cr})$; the other two were classified as clayey $(\mathrm{R})$.

\subsection{Mineral Composition of Sediment}

In Table 3, mineral composition is found, with support of scanning electron microscopy, X-ray diffraction and fluorescence studies, the minerals that make up the sediments of the J. Alzate Dam were observed such as feldspars, halloysite, kaolinite, goethite, hematite among others besides amorphous material. Feldspars are minerals that were found in greater proportion, following halloysite and metahalloysite.

Table 3. Crystallographic composition of surface sediment in three zones.

\begin{tabular}{ccc}
\hline Zone A & Zone B & Zone F \\
Feldspar & Feldspar & Feldspar \\
Hydrated Halloysite & Hydrated Halloysite & Hydrated Halloysite \\
Meta Halloysite & Meta Halloysite & Meta Halloysite \\
Cristobalite & Cristobalite & Cristobalite \\
Chlorite & Mica & Chlorite \\
Illite & Kaolinite & Tridimite \\
- & Dickite & Dickite \\
Amphibol & Amphibol & Amphibol \\
Hematite $\left(\mathrm{Fe} \mathrm{O}_{3}\right)$ & Hematite $\left(\mathrm{Fe} \mathrm{O}_{3}\right)$ & Hematite $\left(\mathrm{Fe}_{2} \mathrm{O}_{3}\right)$ \\
Goethite $(\mathrm{FeO} \cdot \mathrm{OH})$ & Goethite $(\mathrm{FeO} \cdot \mathrm{OH})$ & -
\end{tabular}




\subsection{Results of Metals Evaluation}

Metals $\mathrm{Cd}, \mathrm{Cu}, \mathrm{Fe}, \mathrm{Mn}, \mathrm{Pb}$ and $\mathrm{Zn}$ were evaluated in sediment of three zones of The J. A. Alzate Dam through of chemical speciation and total concentrations, considering criteria MOE, Thomas-Murdoch and EPA.

\subsubsection{Cadmium (Cd) Evaluation in Sediment from A, B and F Zones}

Figure 1 shows the geochemical distribution F1, F2, F3, F4, F5 and F6 for cadmium in sediment obtained in each zone.

Cadmium was concentrated in greater proportion infractions F6, F4, F2 and F3 respectively (Figure 1). In fractions F2, F3 and F4, the concentrations were not very different, which means their easy mobility from exchangeable fraction F1 up to fraction easily reducible F3. Shortage of cadmium in the F5 fraction indicates the low affinity of the metal with organic matter, possibly the presence in this fraction is with the sulfides, since considering Pearson's rules of softness and hardness, [20] both, sulfides and $\mathrm{Cd}^{2+}$ plus negative ion, behave as a base and an soft acid. It is important to note that cadmium presented more affinity with hydrous oxides of Fe than of Mn, but more importantly, it occurs in a significant proportion in the soluble acid fraction (F2), related fraction of this metal with carbonates and can be re-dissolved if will be presented a decrease in $\mathrm{pH}$ of the medium, what would tend to be a high risk metal for biota. Comparing the six fractions for total metal with each criterion for a global evaluation it is observed that for the two Canadian Criteria, all zones exceeded the limit. For EPA, only zone B was exceeded, which resents a greater sedimentation process, besides being the area of greatest contamination since it is the river entrance and as this area extends, the speed of the river decreases with the sedimentation process predominating.

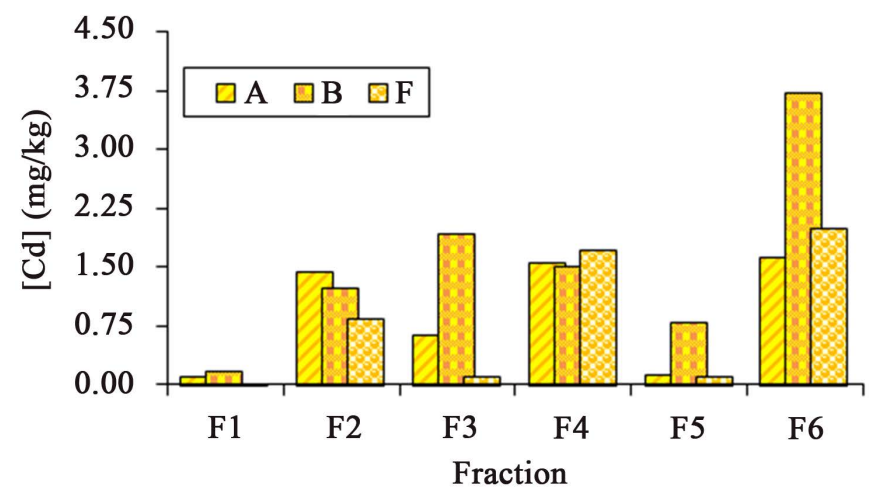

Figure 1. Geochemical distribution of Cd in three surface sediments.

In Table 4, for the cadmium evaluation based on the three criteria, MOE, Thomas-Mudroch and EPA, the six fractions as the first five were considered in the latter case. It is because fraction six is the residual fraction, which is fixed and with little risk of the metal passing into aqueous phase. It is observed in this case that for EPA criterion the limit value was not exceeded, but in zones A, B, F 
the limits of the Canadian Criteria were exceeded. Considering these two criteria, the three zones can be considered contaminated by cadmium and may present a health risk [21] [22].

Table 4. Cd concentrations in three sediments compared to MOE, Thom-as-Mudroch and EPA criteria considering the six fractions and F6 was not considered.

\begin{tabular}{cccc}
\hline $\begin{array}{c}\text { Metal } \\
\mathrm{mg} / \mathrm{kg}\end{array}$ & $\begin{array}{c}\text { MOE } \\
\text { criterion }\end{array}$ & $\begin{array}{c}\text { Thomas-Mudroch } \\
\text { criterion }\end{array}$ & $\begin{array}{c}\text { EPA Criterion } \\
\text { for severe contamination }\end{array}$ \\
\hline Cadmium (Cd) & 1.00 & 1.50 & 6.00 \\
Site & Considering the six fractions & Without considering F6 fraction \\
A & 5.51 & 5.51 \\
B & 9.39 & 9.39 \\
F & 4.82 & 4.82 \\
\hline
\end{tabular}

\subsubsection{Cooper (Cu) Evaluation in Sediment from A, B and F Zones}

In general, in sediments and soils [23], a considerable fraction of copper is attached to organic fraction, seems to form a well-established complex between copper and humic acids. These complexes are based on unions of the type:

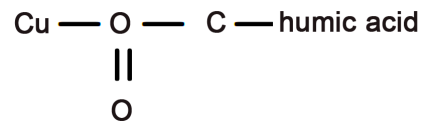

Most of coppers are found in this fraction. One property of $\mathrm{Cu}^{2+}$ is its reduced mobility. Figure 2 shows the geochemical distribution of copper, six fractions were also considered in the three sampling sites. It is observed that this metal has a greater affinity towards fraction F5, related to organic matter and sulfides [1]. Indeed $\mathrm{Cu}$ in the three sites was concentrated in F5, where zones $\mathrm{A}$ and $\mathrm{B}$ had the highest concentration, followed by fraction F6. In fractions F1 and F3, the highest concentration was found in zone B. In F2, zones A and B were almost similar and zone F was slightly lower in zones F. In zones A and F, fraction F3 was similar in concentration.

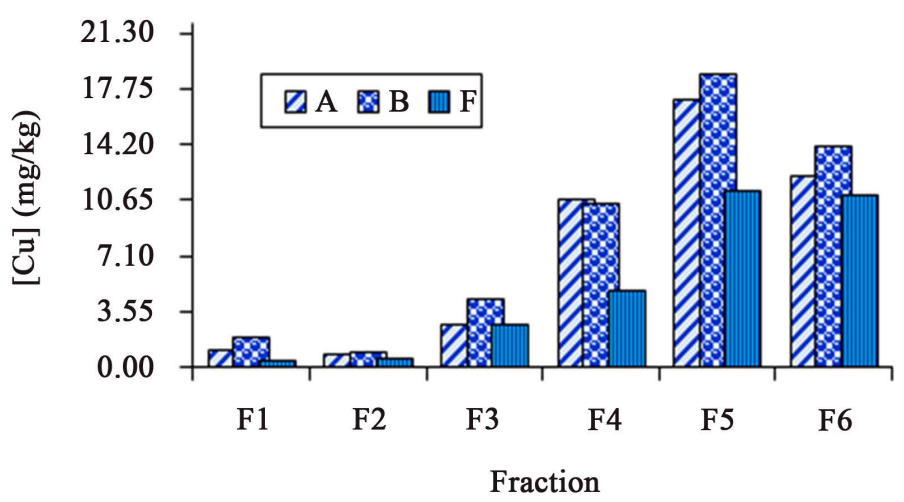

Figure 2. Geochemical distribution of Cd in three surface sediments. 
Table 5 shows $\mathrm{Cu}$ values, considering the six fractions and five fractions which eliminats F6 fraction as in cadmium case. Considering six fractions for MOE criterion, the three zones exceeded the limit, in this case $\mathrm{Cu}$ contamination is considered in the three zones.

Table 5. Cu concentrations in three sediments compared to MOE, Thom-as-Mudroch and EPA criteria considering the six fractions and F6 was not considered.

\begin{tabular}{cccc}
\hline $\begin{array}{c}\text { Metal } \\
\mathrm{mg} / \mathrm{kg}\end{array}$ & $\begin{array}{c}\text { MOE } \\
\text { criterion }\end{array}$ & $\begin{array}{c}\text { Thomas-Mudroch } \\
\text { criterion }\end{array}$ & $\begin{array}{c}\text { EPA Criterion } \\
\text { for severe } \\
\text { contamination }\end{array}$ \\
\hline Cooper (Cd) & 25 & 45 & $\mathbf{5 0}$ \\
Site & $\begin{array}{c}\text { Considering } \\
\text { the six fractions }\end{array}$ & $\begin{array}{c}\text { Without } \\
\text { considering } \\
\text { F6 fraction }\end{array}$ \\
A & 44.45 & 32.30 \\
B & 50.14 & 36.03 \\
F & 30.75 & 19.75 \\
\hline
\end{tabular}

For Thomas-Mudroch criterion, zones $\mathrm{B}$ and $\mathrm{F}$ exceeded the criterion and zone $\mathrm{A}$ is at the limit. For EPA criterion, zones $\mathrm{A}$ and $\mathrm{F}$ did not exceed this criterion and zone $B$ is at the limit. In second case (five fractions) for the MOE criterion only zone F did not exceed the limit value, for Thomas-Mudroch and EPA criteria none of the three zones exceeded the limits. If MOE criterion is considered, the sediments of the three zones present contamination by copper; in this case it can also be a risk to aquifer health [4] [5]. The control of this metal is important, since it represents a risk for Daphnia pulex, dam's typical crustacean since it affects growth and reproduction [24] as it takes its food not only from water but from the sediments. This crustacean and others such as Daphnia magna and Daphnia obtuse, [25] are used for bioassays to evaluate the toxicity of heavy metals [26] due to their high rate of reproduction, its easy handling and sensitivity to contaminants.

\subsubsection{Iron (Fe) Evaluation in Sediment from A, B and F Zones}

In crystallographic study the iron was found as oxide $\left(\mathrm{Fe}_{2} \mathrm{O}_{3}\right)$ and as goethite $(\mathrm{FeOOH})$, where this colloid has an adsorptive surface, it is possible that it is located in the extensive amorphous phase particularly as oxyhydroxides impregnated in clay minerals, kaolinite and quartz, which allows it to sequester metals as $\mathrm{Cd}, \mathrm{Cu}, \mathrm{Pb}$ and $\mathrm{Zn}$. Figure 3 shows a geochemical distribution of this metal, in general the concentrations were high, where there may be an anthropogenic and another part of natural geochemistry. It can be seen in Figure 3 that largest accumulation was in fractions F6, F4 and F5, respectively, where highest concentration was in zone $\mathrm{B}$ and lowest concentration in zone F. 


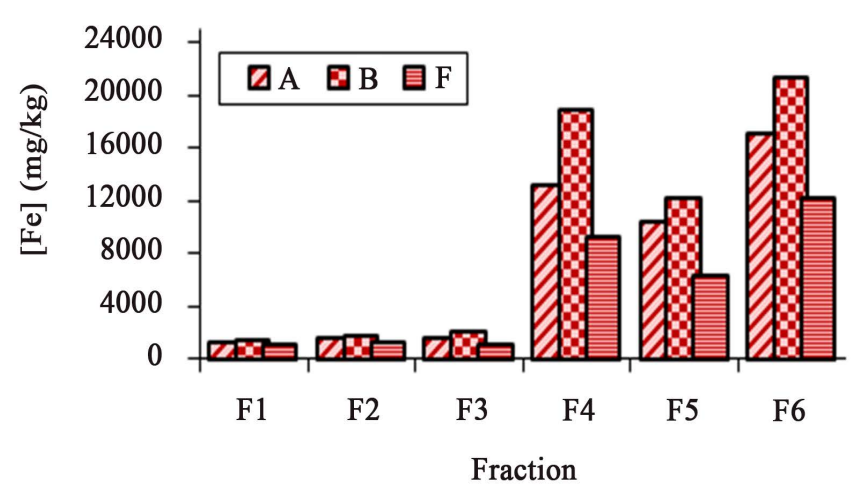

Figure 3. Geochemical distribution of Cd in three surface sediments.

Considering the criteria already described, Table 6 presented the evaluation for Fe. In six fractions case the three zones exceeded the MOE and EPA criteria, in case of Thomas-Mudroch criterion only zone B exceeded it and zone A was almost in the limit. In case of five fractions, where only the first five fractions were considered, for MOE criterion the three zones exceeded the limit, for EPA criterion, zones A and B exceeded the limit and for Thomas-Mudroch criterion, the limit concentration was not exceeded in none of three zones.

Table 6. Fe concentrations in three sediments compared to MOE, Thom-as-Mudroch and EPA criteria considering the six fractions and F6 was not considered.

\begin{tabular}{cccc}
\hline $\begin{array}{c}\text { Metal } \\
\mathrm{mg} / \mathrm{kg}\end{array}$ & $\begin{array}{c}\text { MOE } \\
\text { criterion }\end{array}$ & $\begin{array}{c}\text { Thomas-Mudroch } \\
\text { criterion }\end{array}$ & $\begin{array}{c}\text { EPA Criterion } \\
\text { for severe } \\
\text { contamination }\end{array}$ \\
\hline Iron (Fe) & 10,000 & 45,500 & $\mathbf{2 5 , 0 0 0}$ \\
Site & $\begin{array}{c}\text { Considering } \\
\text { the six fractions }\end{array}$ & $\begin{array}{c}\text { Without considering } \\
\text { F6 fraction }\end{array}$ \\
A & 44620.51 & 27542.87 \\
B & 57152.38 & 35854.05 \\
F & 30559.42 & 18424.80 \\
\hline
\end{tabular}

\subsubsection{Manganese (Mn) Evaluation in Sediment from A, B and F Zones}

Figure 4 shows the geochemical distribution of manganese, six fractions were also considered in the sampling. In Mn case, its origin in sediments appears to be geological and the greater concentration in sediments of the three zones indicates a greater affinity towards sedimentable particles, since concentrations in $\mathrm{F} 1$ fraction is somewhat elevated with respect the previous metals and is related to fresh manganese colloids, manganite type $(\mathrm{MnOOH})$. The higher concentration in site A indicates an additional contribution of sludge carried by Lerma River, highest concentration in the three zones was found in fraction F6, followed by F3, where highest concentration of mobile $\mathrm{Mn}$ is present. 


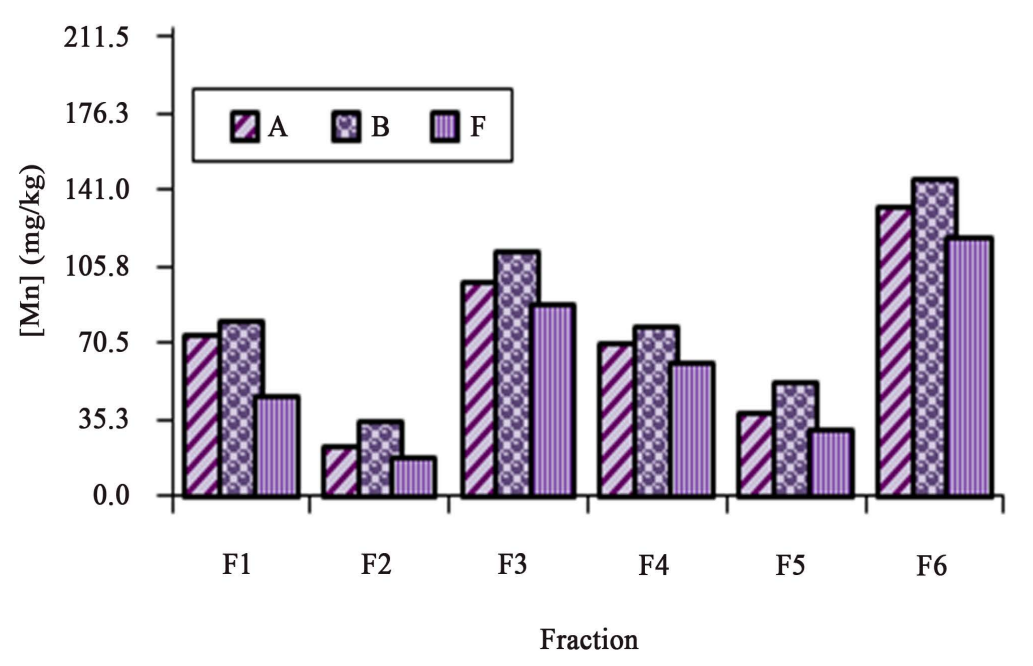

Figure 4. Mn geochemical distribution in three surface sediments.

Table 7 showed the sediment quality evaluation with respect to this metal according the three criteria. Also six fractions were evaluated and the first five fractions. For MOE criterion no limit value has been reported, so for this metal only Thomas-Mudroch and EPA criteria were considered. In neither case were the limits exceeded. In the six fractions case, under the influence of F6 fraction, which is the residual and immobile fraction, zone B was at limit.

Table 7. Mn concentrations in three sediments compared to MOE, Thomas-Mudroch and EPA criteria considering the six fractions and F6 was not considered.

\begin{tabular}{cccc}
\hline $\begin{array}{c}\text { Metal } \\
\mathrm{mg} / \mathrm{kg}\end{array}$ & $\begin{array}{c}\text { MOE } \\
\text { criterion }\end{array}$ & $\begin{array}{c}\text { Thomas-Mudroch } \\
\text { criterion }\end{array}$ & $\begin{array}{c}\text { EPA Criterion } \\
\text { for severe } \\
\text { contamination }\end{array}$ \\
\hline Manganese (Mn) & - & $\mathbf{1 6 2 5}$ & $\mathbf{5 0 0}$ \\
Site & $\begin{array}{c}\text { Considering } \\
\text { the six fractions }\end{array}$ & $\begin{array}{c}\text { Without } \\
\text { considering } \\
\text { F6 fraction }\end{array}$ \\
A & 432.51 & 299.86 \\
B & 497.87 & 352.63 \\
F & 358.51 & 239.89 \\
\hline
\end{tabular}

\subsubsection{Lead ( $\mathrm{Pb}$ ) Evaluation in Sediment from A, B and F Zones}

In speciation diagram (Figure 5) it is observed that $\mathrm{Pb}$ is distributed in the less mobile fractions, perhaps due to high content of clays (F6) and amorphous solids of $\mathrm{Fe}$ and $\mathrm{Mn}$ in the sediment, since these materials present large adsorption surfaces. It is observed that in zone B, fraction F2 (acid-soluble) had the highest concentration with respect to $\mathrm{A}$ and $\mathrm{F}$ zones, which indicates its relation to carbonates, where it can be exchanged with calcium as well as organic matter and sulfides in relation to mineralogical composition of the sediment. 


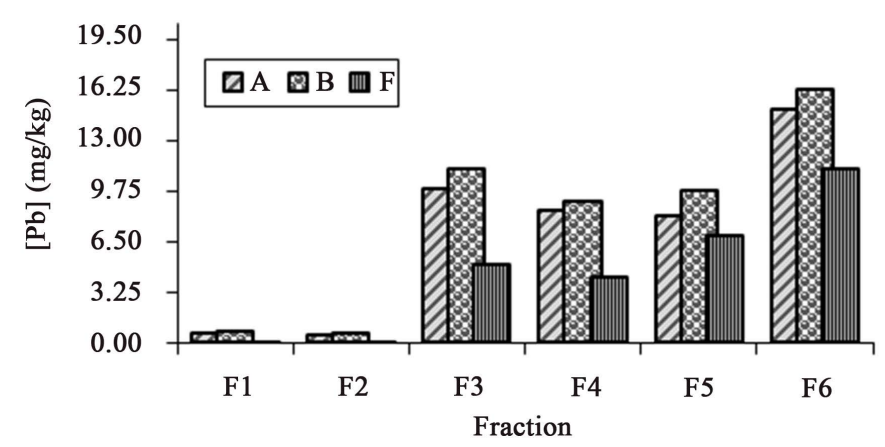

Figure 5. $\mathrm{Pb}$ geochemical distribution in three surface sediments.

Lead presence in sediments is due to the anthropogenic contributions of this metal, coming from industrial wastewater that Lerma River transports. According to chemical speciation results, this metal tends to concentrate towards the fractions with less mobility. Lead accumulation infractions F3, F4, F5 and F6, where the chemical mobility decreases respectively, leads to think that sediments work as traps for this metal, which means a decrease in the probability that it will be easily released to aqueous phase.

Table 8 shows the sediment quality evaluation with respect to this metal according the three criteria; the six fractions and first five fractions were evaluated how in the other cases. In six fractions case for this metal the MOE and Thomas-Mudroch criterion was exceeded in zone A, but not for the EPA criterion. For zones $\mathrm{B}$ and $\mathrm{F}$ none of the three criteria were exceeded.

Table 8. $\mathrm{Pb}$ concentrations in three sediments compared to MOE, Thomas-Mudroch and EPA criteria considering the six fractions and F6 was not considered.

\begin{tabular}{cccc}
$\begin{array}{c}\text { Metal } \\
\mathrm{mg} / \mathrm{kg}\end{array}$ & $\begin{array}{c}\text { MOE } \\
\text { criterion }\end{array}$ & $\begin{array}{c}\text { Thomas-Mudroch } \\
\text { criterion }\end{array}$ & $\begin{array}{c}\text { EPA Criterion } \\
\text { for severe contamination }\end{array}$ \\
\hline Lead $(\mathrm{Pb})$ & 50 & 50 & 60 \\
Site & Considering the six fractions & Without considering F6 fraction \\
A & 54.66 & 34.61 \\
B & 30.59 & 22.57 \\
F & 25.71 & 17.52 \\
\hline
\end{tabular}

In the case of the five fractions (elimination of fraction F6), none of the three criteria was exceeded in any of the three zones. Lead was accumulated in higher concentration in F6 and because this fraction is totally immobile, its elimination is important since the values, when are compared with the three criteria, allow to evaluate each area as not contaminated by lead. It is important to be careful with this metal especially for the Daphnia pulex that can absorb it and bioaccumulate as it takes its food from sediments, being that this crustacean is an important food for the fish. It is necessary bear in mind that these metals type in biota generates a series of metabolic, physiological, behavioral and ecological effects [27]. 


\subsubsection{Zinc (Zn) Evaluation in Sediment from A, B and F Zones}

Figure 6 shows the Zn geochemical distribution in sediment of the three sites, a mobility of this metal was observed, where it is related to components present in the different fractions, a higher affinity is observed with Fe oxides (Fraction F4), according to Figure 6, there is a similar affinity with Mn colloids (Fraction F3) and organic matter (Fraction F4). Fraction F2 presented important values for this metal, which relate it to carbonates present in sediment. $\mathrm{Zn}$ is considered as a hard acid of Pearson [20] this may explain its similarity with calcium and its affinity with hard bases, reason why in fraction F4 it is more related with organic matter than to sulfides in these sediments.

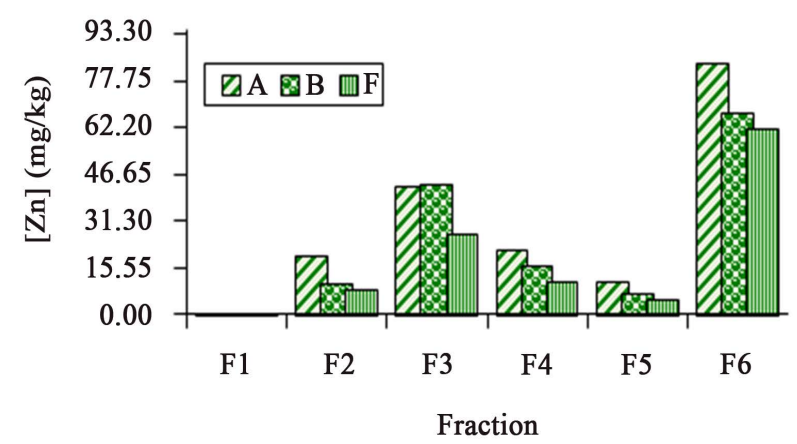

Figure 6. Zn geochemical distribution in three surface sediments.

Table 9 presented the Zn evaluation according to the three criteria, in the first case where six fractions case were considered; all zones exceeded the limit values of MOE and Thomas-Mudroch criteria; for EPA criterion no zone was exceeded. In the case where fraction F6 was eliminated, in no zones values of the three criteria were exceeded.

Table 9. Zn concentrations in three sediments compared to MOE, Thomas-Mudroch and EPA criteria considering the six fractions and F6 was not considered.

\begin{tabular}{cccc}
\hline $\begin{array}{c}\text { Metal } \\
\mathrm{mg} / \mathrm{kg}\end{array}$ & $\begin{array}{c}\text { MOE } \\
\text { criterion }\end{array}$ & $\begin{array}{c}\text { Thomas-Mudroch } \\
\text { criterion }\end{array}$ & $\begin{array}{c}\text { EPA Criterion } \\
\text { for severe contamination }\end{array}$ \\
\hline Zinc $(\mathrm{Zn})$ & 100 & 105 & 200 \\
Site & Considering the six fractions & Without considering F6 fraction \\
A & & 177.28 & 93.97 \\
B & 144.28 & 77.28 \\
F & 111.42 & 49.56 \\
\hline
\end{tabular}

Despite of $\mathrm{Zn}$ is a metal required by organisms, an increase in concentrations makes it toxic to aquatic organisms. In the aquatic environment, $\mathrm{Zn}$ is mainly associated with suspended matter before accumulating in the sediment [28]. Evidence on the bioavailability of this metal in sediments has been documented in investigations of plants and invertebrates that feed on them, such as mollusks and algae, which reflect the zinc concentrations in sediments. Other researchers 
have indicated that organisms related to sediments have higher $\mathrm{Zn}$ concentrations than the organisms that inhabit in aqueous layer.

\section{Conclusions}

In so far as the texture and granulometry of the sediment, it was observed that sediments in zones $\mathrm{B}$ and $\mathrm{F}$, that correspond practically to the dam, predominate clays, while in zone A, corresponding to the channel of the Lerma river. Silt was found in greater proportion, although it also drags clay and sand. Considering composition, feldspars and halloysite were found in the three zones. It is important to mention the goethite presence, because it has an important adsorption surface for metals, in addition to amorphous organic matter, where humic material presence also functions as adsorbent surface. These surfaces combined with clays are main materials like trap metals, as observed in geochemical $\mathrm{Cd}$ and $\mathrm{Zn}$ distribution, which was the most mobile metals since it was found more associated with carbonates (Fraction F2) and oxides as Fe and Mn, where surface goethite is probably the main surface (Fraction F4). In Cu case, the affinity for organic matter and sulfides is very noticeable (Fraction 5), although it was also concentrated in fraction $\mathrm{F} 4$ related to iron oxides. $\mathrm{Pb}$ presented a strong association with colloids of $\mathrm{Mn}, \mathrm{Fe}$, organic matter and sulphides in almost the same proportions (F3, F4 and F5 respectively) and very little relation with components of F1 and F2 fractions opposite of $\mathrm{Cd}$. Concentration elevated for $\mathrm{Cd}$ and $\mathrm{Pb}$ was found in residual fraction F6. More elevated copper concentration was more accumulated in components of fraction F5. It was observed with respect to fraction F6 that zone B in general had the highest accumulation of all five metals. The association of these metals to sediment does not imply their total immobilization, since on the one hand, fine solid particles can be dragged towards other points of the reservoir, in which the physicochemical characteristics (including the $\mathrm{pH}$ and water aggressiveness) are different propitiating the re-dissolution of more labile or more mobile fractions (singularly for Cd). Regarding Fe and Mn, as indicated in sediment characterization analysis, the origin is basically geological. In case of $\mathrm{Fe}$, it present as goethite $(\mathrm{FeO} \cdot \mathrm{OH})$ and $\mathrm{Mn}$ as manganite $(\mathrm{MnOOH})$ are surface that can act as an adsorption surface for $\mathrm{Cd}, \mathrm{Cu}, \mathrm{Pb}$ and $\mathrm{Zn}$, and that is, as sequestrants of these metals.

Finally, when the three criteria are compared, considering six fractions and first five, cadmium in the three zones exceed the limits of Canadian criteria, so it can be considered a pollutant for the sediment. In copper case, the MOE criterion limit was exceeded, considering only this criterion. The sediment is contaminated by copper. For $\mathrm{Pb}$ in none of the cases where the limits of these criteria exceed, at least in this study, is not considered the sediments contaminated by $\mathrm{Pb}$ in any of the three zones. It is important to consider better the first five fractions that are most mobile and present the risk of moving to aqueous phase, but not fraction F6 that is practically immobile, since metals are trapped in crystalline networks and are able to determine them whether it is necessary to use very acid digestions. 
Knowing the composition and morphology of these sediments can provide information to understand the mobility of different heavy metals it contains and potential health risk which can lead to the establishment of its purification capacity. Considering everything discussed in this article, studying the sediment plays an important role in water bodies. It's important conclude like many authors in this research field, that analytical measurements for specific total metal in an environmental and biological systems are insufficient. Among the most important metal speciation analysis is the assessment of the index of toxicity impacts of one specific metal and determination of ecological risk... Speciation analysis is an also analytical tool particularly used for the elucidation of the chemical form(s) as well as the quantitative estimation of a specific element when conducting toxicological and biochemical investigations [1] [3] [7] [8] [12] [21] [29].

\section{References}

[1] Barceló-Quintal, I., Bussy, A.L. and Solís-Correa, H.E. (2005) Metal Interactions with Water and Sediment in Freshwaters. In: Palomar, M., Ed., Chapter 10: Applications of Analytical Chemistry in Environmental Research, Research Signpost, Thiruvananthapuram, 161-188.

[2] Linnik, P.M. and Zubenko, I.B. (2000) Role of Bottom Sediments in the Secondary Pollution of Aquatic Environments by Heavy-Metal Compounds. Lakes \& Reservoirs. Research and Management, 5, 11-21

[3] Förstner, U. and Calmano, W. (1993) Sediment Quality Objectives and Criteria Development in Germany. Water Science \& Technology, 28, 307-316.

https://doi.org/10.2166/wst.1993.0629

[4] Förstner, U. (1986) Changes in Metal Mobilities in Aquatic and Terrestrial Cycles. In: Patterson, J. and Passino, R., Eds., Proceedings of the International Symposium on Metal Speciation, Separation and Recovery, Chicago, Lewis Publishing Company, 3-26.

[5] Salomons, W. and Förstner, U. (1980) Trace Metals Analysis on Polluted Sediments. Part II: Evaluation of Environmental Impact. Environmental Technology Letters, 1, 506-517. https://doi.org/10.1080/09593338009384007

[6] Barceló, I., Bussy, A.L., Solís, H., Ávila, P. and Campos, R. (2002) Determination of the Adsorptive Affinity towards Cadmium of Untreated and Treated Sediments. XIII National Congress of FEMISCA, Guanajuato City, 17-20 April 2002, 1-12

[7] Tessier, A., Campbell, P.G.C. and Bisson, M. (1979) Sequential Extraction Procedure for the Speciation of Particulate Metals. Analytical Chemistry, 51, 844-851. https://doi.org/10.1021/ac50043a017

[8] Barceló-Quintal, I.D., Salazar-Peláez, M.L., García-Albortante, J., Domínguez-Mariani, E., López-Chuken, U.J. and Gómez-Salazar, S. (2013) Evaluation of Water Quality Index in Lerma River Upper Basin. Journal of Environmental Protection, 4, 98-103. https://doi.org/10.4236/jep.2013.47A012

[9] Barceló, Q.I.D. (2000) Study of the Mobility of $\mathrm{Ca}, \mathrm{Cd}, \mathrm{Cu}, \mathrm{Fe}, \mathrm{Mn}, \mathrm{Pb}$ and $\mathrm{Zn}$ in Sediments of José Antonio Alzate Dam in the State of Mexico. Doctoral Thesis, Faculty of Engineering, Autonomous University of the Mexico State, Toluca.

[10] Quecholac, P.X. (2008) Mobility Evaluation of Al, Cu, Co, Mn, Ni, and Fe in Sludge of Treatment and Sediments of an Aquatic Body through Chemical Speciation Me- 
thodology. Environmental Engineering Thesis, Metropolitan Autonomous University, Mexico City.

[11] Badillo-Camacho, J., Murillo-Delgado, J.O., Barcelo-Quintal, I.D., Zarate del Valle, P.F., Orozco-Guareño, E., López-Chuken, U.J. and Gomez-Salazar, S. (2016) Heavy Metals Speciation in Sediments of a Mexican Tropical Lake. Mexican Journal of Chemical Engineering, 15, 565-573.

[12] Benson, N.U., Anake, W.U. and Olanrewaju, I.O. (2013) Analytical Relevance of Trace Metal Speciation in Environmental and Biophysicochemical Systems. American Journal of Analytical Chemistry, 4, 633-641. https://doi.org/10.4236/ajac.2013.411075

[13] Avila-Pérez, P., Zarazuá, G., Carapia, L., Tejeda, S., Barceló-Quintal, I. and Martinez, T. (2011) Concentration of Elements in Suspended Matter Discharges to Lerma River, Mexico. Journal of Radioanalytical and Nuclear Chemistry, 287, 383-391. https://doi.org/10.1007/s10967-010-0887-8

[14] Avila, P.P., Balcázar, M., Zarazúa, O.G., Barceló, Q.I. and Díaz, D.C. (1999) Heavy Metal Concentrations in Water and Bottom Sediments of a Mexican Reservoir. Science of the Total Environment, 234, 185-196. https://doi.org/10.1016/S0048-9697(99)00258-2

[15] National Water Commission (CNA) (1993) Dams of Mexico, Information and Citizen Participation Management. Government Report of the State of Mexico, Vol. 5, Impergraph.

[16] Ontario Ministry of the Environment (MOE) (1976) Evaluating Construction Activities Impacting on Water Resources Part III A. Handbook for Dredging and Dredged Material Disposal in Ontario. Legislation Policies, Sediment Classification and Disposal Options. Ontario Ministry of the Environment and Energy, Toronto, 49.

[17] Thomas, R.L. and Mudroch, A. (1978) Small Craft Harbours-Sediment Survey, Lakes Ontario, Erie and Lake St. Clair 1978: Dredging Summary and Protocol. Report to the Great Lakes. Biological Limnology Laboratory, Ontario.

[18] United States Environmental Protection (EPA) (1975) Agency Regulations Governing Discharge of Dredged or Filled Material in Navigable Waters. Federal Register, 40, 292-298.

[19] Calmano, W. and Förstner, U. (1983) Chemical Extraction of Heavy Metals in Polluted River Sediment in Central Europe. Science of the Total Environment, 28, 77-88. https://doi.org/10.1016/S0048-9697(83)80009-6

[20] Pearson R.G. (1963) Hard and Soft Acids and Bases. Journal of the American Chemical Society, 85, 3533-3539. https://doi.org/10.1021/ja00905a001

[21] López-Galván, E., Barceló-Quintal, I., Solís-Correa, H.E., Bussy, A.L., Avila-Pérez, P. and Martínez-Delgadillo, S. (2010) Calculation of the Ecological Risk Index in the José Antonio Alzate Dam, State of Mexico. Biological Trace Element Research, 135, 121-135. https://doi.org/10.1007/s12011-009-8501-Z

[22] Barceló-Quintal, I., Solís-Correa, H.E., Ávila-Pérez, P., López-Galván, E., Gómez-Salazar, S. and García-Albortante, J. (2012) Determination of Distributions of $\mathrm{Cd}, \mathrm{Cu}$ and $\mathrm{Pb}$ Concentrations in Sediments of a Mexican Reservoir to Infer Their Environmental Risk. Biological Trace Element Research, 148, 122-132. https://doi.org/10.1007/s12011-012-9458-x

[23] Boyd, S.A., Sommers, L.E., Nelson, D.W. and West, D.X., (1983) Copper (II) Binding by Humic Acid Extracted from Sewage Sludge: An Electron Spin Resonance Study. Soil Science Society of America Journal, 47, 43-46. 
https://doi.org/10.2136/sssaj1983.03615995004700010008x

[24] De Schamphelaere, C. and Janssen, C. (2004) Effects of Dissolved Organic Carbon Concentration and Source, $\mathrm{pH}$, and Water Hardness on Chronic Toxicity of Copper to Daphnia magna. Environmental Toxicology and Chemistry, 23, 1115-1122. https://doi.org/10.1897/02-593

[25] Gaete, H. and Paredes, K. (1996) Chemical Contaminants Mixtures Toxicity of on the Daphnia magna Cladocero. International Journal of Environmental Pollution, 12, 23-28.

[26] Barata, C., Baird, D.J., Nogueira, A.J., Soares, A.M. and Riva, M.C. (2006) Toxicity of Binary Mixtures of Metals and Pyrethroid Insecticides of Dapnia magna Straus. Implications for Mult-Substance Risks Assessment. Aquatic Toxicology, 78, 1-14. https://doi.org/10.1016/j.aquatox.2006.01.013

[27] Shcumatcher, M., Domingo, J., Llobet, J. and Corbella, J. (1995) Variations of Heavy Metals in Water, Sediments and Biota from the Delta of the Ebro River, Spain. Journal of Environmental Science and Health, 30, 1361-1372.

[28] Utgikar, V., Chaudhary, N., Koeniger, A., Tabak, H., Haines, J. and Govind, R. (2004) Toxicity of Metals and Metal Mixtures: Analysis of Concentration and Time Dependence for Zinc and Copper. Water Research, 38, 3651-3658. https://doi.org/10.1016/j.watres.2004.05.022

[29] Fytianos, K. and Lourantou, A. (2004) Speciation of Elements in Sediment Samples Collected at Lakes Volvi and Koronia, N. Greece. Environment International, 30, 11-17. https://doi.org/10.4236/ajac.2013.411075 